\title{
Employers' Use of Lockouts under the Employment Contracts Act 1991: A New Balance of Power?
}

\author{
Rebecca Macfie*
}

Since May 1991 lockouts have become a more familiar feature of New Zealand's industrial relations environment, and have been used to powerful effect by employers on a number of well-publicised occasions. It has been argued that the Employment Contracts Act is not responsible for this development. This argument rests primarily on the fact that the ECA's lockout provisions were inherited from the Labour Relations Act. This paper examines the case law on lockouts under the ECA, and argues that the bargaining environment created by the ECA has made the lockout a more powerful, and therefore more attractive, weapon than was the case under the LRA.

Since the 1987 Labour Relations Act, Parliament has recognised the right of workers to strike and employers to lock out, free of the threat of civil action, in certain closely defined circumstances. These tools of industrial bargaining are, in theory, equal and counterbalancing, giving employers and employees limited right to bring coercive pressure to bear on the opposite party.

As Colgan J commented in NZ Public Service Association v Designpower NZ Ltd 16/4/92 WEC 17A/92:

It is ... noteworthy that the power to lawfully lockout employees is often said to be the mirror image of and quid pro quo of the right or power of employees to strike to the same end.

Since the enactment of the Employment Contracts Act (ECA), lockouts have become a much more prominent feature of New Zealand's industrial relations landscape, and a considerably more popular element of employers' industrial relations armoury. It will be argued here that this trend is a product of the ECA's deregulated and decentralised bargaining framework, which, combined with the definition of lockout inherited from the Labour Relations Act (LRA), has led to a body of case law establishing the lockout, and in particular the so-called "partial lockout" whereby selected portions of employees' contracts are breached, as an extremely powerful tool in employers' hands. As a consequence, the tenet of industrial law espoused by Colgan $\mathrm{J}$ in Designpower and quoted above no longer reflects the reality of industrial relations, and the balance of power has swung firmly in favour of employers.

* Freelance writer, Christchurch 


\section{The role of lockouts prior to the ECA}

Despite New Zealand's industrial relations climate being marred by conflict, particularly in the 1960s and 1970s (Brosnan et al., 1990), employers were generally loathe to use the lockout tool. Hughes (1990) noted that lockouts had historically been of little significance in New Zealand labour law, and that this had been explained on the basis that employers were restrained from using the lockout weapon by the obligation, until 1981, to pay wages to locked out workers, or because of employers' concern for their workers' welfare. A more significant reason for the relative dearth of case law on lockouts, argued Hughes, was the restrictive definition of lockout which comprised both the employers' action and its motive, and the consequent difficulty of proving a lockout had occurred.

Such case law as did develop prior to the ECA did, however, hint at the unrealised power of the lockout weapon. The notion that a lockout could be something other than a literal locking of the factory gates was well established under the LRA. In NZ Dairy Food and Textile Workers' Union v Cavalier Bremworth Ltd [1991] 2ERNZ (WLC32), the union successfully alleged the employer's action in imposing a new shift system on workers was a lockout. In NZ Seamens' IUOW \& Federated Cooks and Stewards' Union etc v Shipping Corporation of New Zealand [1989] 1 NZILR 6, the idea that a mass dismissal could constitute a lockout was recognised. The Public Service Association, in NZ Public Service Association v Armourguard Rescue Services Ltd [1989] 3 NZILR 343, recognised by implication the concept of the "partial lockout" by arguing (unsuccessfully) that the introduction of a new rescue fire appliance before the customary consultative discussions on manning had been held was a lockout. Similarly, in NZ Airline Pilots' Association v Air New Zealand [1991] 2 ERNZ (AEC35), the plaintiff union argued (again, unsuccessfully) that the airline's requirement that pilots be clean-shaven was a lockout. It is noteworthy that in each of these cases the employer argued its action was not a lockout, including in the Shipping Corporation case where the lockout was held to be lawful. In contrast, in the leading cases on lockouts under the ECA the employer has expressly ensured its actions fell within the definition of lockout. This points to a new consciousness among employers of the potency of the lockout which was absent prior to the 1991 Act.

It is arguable that in the climate of high inflation that prevailed in the 1970 s and $1980 \mathrm{~s}$ employers did not need to resort to lockouts to achieve their aims. For example, in the 1989 and 1990 wage rounds under the LRA, wage settlements were markedly below the rate of inflation. The 1989 wage round followed a $4.5 \%$ path, while inflation for the December 1989 quarter was $7.2 \%$, and in 1990 the Council of Trade Unions-Labour Government "growth agreement" kept most workers in the collective bargaining system to a $2 \%$ pay rise, while inflation for the December quarter that year ran at $4.8 \%$. Analysis by Harbridge of the five wage rounds between 1984 and 1988/89 showed neither award nor non-award settlements had kept pace with inflation as measured by the CPI, largely because the effects of GST had not been compensated for (Harbridge, 1990).

But the wage attrition caused by inflation during this period did not address the many other issues which arose as key employer concerns during the very difficult trading conditions of the late 1980s and beginning of the 1990s. For example, following the deregulation of shop trading hours in 1989 there was enormous pressure from retail employers, confronted with heightened competition and a depressed retail trading environment, for cuts to weekend penal rates. Yet there was no attempt to enforce these demands through the use of lockouts. 
The same observation could be made about other sectors of the economy during this period - among others, the hotel, transport, stores, education sectors - where employers sought major concessions on such issues as penal rates, hours of work and the use of casual workers.

The historical rarity of lockouts was noted by Geare (1988), who suggested:

"Lockouts are so few in number because there is rarely any need for employers to use a lockout - even if they want a stoppage of work. If they really want a stoppage, then in practically all cases they can trigger a strike either by their actions or by their refusal to act."

A more important reason, and one which will be explored later in this paper, lies in the influence of the highly regulated and centralised system of award bargaining, which , captured $79 \%$ of all unionised private sector workers and $52 \%$ of unionised public sector employees in 1989/90 (Harbridge, 1991). The practicalities of this system meant that for lockouts to be effective employers would have had to act in a highly organised and disciplined manner, but the system itself militated against this degree of cohesion. As has often been commented, the process of award bargaining was relatively remote from most employers, who by and large accepted the outcome as a fait accompli. Indeed, for many employers the system had benefits: Harbridge (1991, supra) noted that the award system provided low wage outcomes and low transaction costs for employers, and McAndrew and Hursthouse (1990) found "little overt dissatisfaction with patterns of interaction between employers and unions, and relatively little dissatisfaction with the outcomes of the existing system." Therefore, it is arguable that lockouts were rare in the pre-ECA environment because employers lacked the necessary motivation.

\section{The 1991 Act: the new order}

To test the proposition that the ECA has made the lockout a more accessible and effective weapon than it was under the LRA, it is necessary first to canvass the relevant provisions of both statutes.

The statutory definition of lockout in s62 of the ECA is identical to the LRA's definition at $s 232$. A lockout is the act of an employer in closing, suspending, or discontinuing all or part of its business, or wholly or partially discontinuing the employment of any workers, or in breaking some or all of its contracts of service, or in refusing to engage workers normally engaged by the employer, with a view to compelling any workers, or to aid any other employer to compel workers, to accept terms of employment or to comply with any demands made by the employer.

The circumstances in which strikes and lockouts are unlawful and lawful are laid out in ECA s63 and s64 respectively. Section 63 makes unlawful any strike or lockout which occurs while a collective employment contract (CEC) relating to the employees involved is in force; or if it relates to a dispute or a personal grievance; or to any matter dealt with under Part I (freedom of association) of the ECA; or if the action concerns whether more than one employer will be bound by a CEC; or if the required notice provisions in essential services have not been complied with. Strikes and lockouts are lawful under the ECA if they are not unlawful under s63, and if they relate to the negotiation of a CEC for the employees concerned.

The counterparts to these sections under the LRA were s223 and s234. The principal 
differences between the two statutes are that the LRA allowed strikes and lockouts over disputes of interest when the relevant award or agreement had no more than 60 days until it expired, or if they related to a "new matter" (a concept absent from the ECA), or to the negotiation of a redundancy agreement. The LRA rendered unlawful strikes and lockouts over disputes, personal grievances, demarcation disputes, union membership or change of union coverage, cancellation of union registration, or where the action occurred more than 60 days before the expiry of the relevant award or agreement, or in essential industries where the notice requirements had not been met. The ECA mirrors the LRA's provision that strikes and lockouts on health and safety grounds are not unlawful.

Hence, the ECA's lockout provisions owe much to the LRA. In practice, however, profound differences have emerged in terms of employers' willingness and ability to use lockouts to effect change. The reason for this lies in the interplay between the ECA's lockout provisions and its bargaining framework.

The ECA has shifted industrial relations from a corporatist model to a contractualist model (Churchman, 1991). It provides for individual and collective contracts which bind only the individual employers and employees who are direct parties to the contracts. Collective contracts remain in force as collective instruments only until their expiry dates. Unless a new CEC is negotiated, employees are automatically deemed to be on individual employment contracts (IECs) which incorporate the terms of the expired CEC. Union membership is voluntary and unions have no special status in the industrial process. Workers may select any bargaining agent - not necessarily a union - to represent them, or they may represent themselves. The employer must recognise its workers' authorised bargaining agents, but the ECA does not compel it to negotiate with those agents. The bargaining process itself is non-prescriptive, and can take any course the parties choose. The ECA is neutral as to whether settlements are achieved, and leaves the negotiation of employment contracts entirely in the hands of the parties.

In contrast, the LRA provided for awards to bind all workers and employers in the industry or occupation to which the document applied, and for agreements to bind all workers whose employers were signatories. Unions, rather than individual workers, were parties to awards and agreements, and unions had recognised bargaining rights on behalf of workers. The LRA provided for awards and agreements to remain in force as collective documents for up to three years beyond their expiry dates. Compulsory union membership under awards and agreements could be achieved either by ballot of workers or agreement with the employer negotiators, and unions had exclusive coverage rights over workers captured by their membership rules. The negotiation of awards was highly regulated through the process of compulsory conciliation, whereby employer and union advocates formed conciliation councils chaired by mediators employed by the Government Mediation Service. If negotiations broke down, the dispute would be referred to the Arbitration Commission, which would endeavour to get the parties back to the bargaining table or, if requested by both parties, could arbitrate a settlement.

The LRA also provided for agreements, which were achieved by voluntary negotiation and bound only the employers and unions who actually negotiated them. However, until the 1990 Labour Relations Amendment Act, unions had exclusive power to cite employers out of award coverage for negotiations for a separate agreement. The amendment gave employers with more than 50 workers power to initiate the citing out process. In common with the ECA, the LRA, up until the 1990 amendment, contained no provision for compulsory arbitration, although the 1990 amendment introduced compulsory final offer arbitration in circumstances where protracted negotiations had failed to achieve a settlement. 
The outcome of this radical change in the bargaining process has been a rapid shift from large, multi-employer awards to a predominance of enterprise-based contracts (Harbridge and Moulder, 1992). It is in the context of the ECA's decentralised, face to face mode of bargaining that the effective power of the lockout has been magnified.

\section{Lockouts under the Employment Contracts Act}

The first case of importance in testing this proposition is Prendergast $v$ Associated Stevedores [1991] 2ERNZ (AEC20). This followed an earlier decision of the Labour Court (sitting as the Employment Tribunal) between the same parties, which held that the provisions of the employees' expired award restricting the use of casual labour by the employer formed part of their IECs under s19(4) of the ECA. Following that decision, the employer notified the employees that it intended breaching, under s62(1)(c), the provisions of their IECs relating to the use of casual labour, until they agreed to a new CEC which eliminated the very provisions it intended breaching, and to which the Waterfront Workers' Union was not a party. Rejecting the employees' pleas for compliance orders, interim and permanent injunctions, Travis $\mathrm{J}$ held that the employer had been using a "legitimate tool of industrial relations, namely the threat of a lockout", to strengthen its bargaining position.

This case, then, established that employers who failed to achieve what they wanted through negotiations for a CEC could lawfully impose the specific changes they sought under the protection of $\mathrm{s} 62(1)(\mathrm{c})$. This form of action, conveniently dubbed the "partial lockout" because it amounts to something less than a literal locking out of the employees from their place of work, was further developed in Paul and Ors v NZ Society for the Intellectually Handicapped Inc 15/1/92 WEC 1/92 W 127/91. The IHC, faced with a financial crisis, was seeking two CECs covering different sections of its workforce, and wanted changes to its employees' terms and conditions to achieve significant cost savings for the organisation. When negotiations with the employees' bargaining agent failed to yield agreement, IHC notified the employees it intended breaching those provisions of their IECs that it wanted eliminated from the proposed CEC. They were told the action would save the IHC $\$ 4.2$ million within six months, and that it was being taken with a view to compelling them to accept new terms of employment.

Unlike the Prendergast case, the IHC action threatened to have an immediate impact on employees' wage packets. They claimed the action was a breach of their IECs and sought from the Employment Court a compliance order and injunction restraining IHC from committing the breaches. Castle J found IHC's action was a lockout under s62(1)(c) in that "fundamental terms" of the employees' contracts had been breached. The lockout related to the negotiation of a CEC and was therefore lawful under s64 (1)(b). In using the "fundamental terms" test of whether the employees' contracts had been breached, Castle J drew on the Armourguard case (supra), heard under the LRA. In that case, which concerned whether the employer's action in introducing a new rescue fire appliance prior to customary consultative discussions with the union was a lockout, and if so whether it was unlawful, Goddard CJ said:

If the [new fire appliance] is introduced, and the respondent requires the workers to operate it, would that requirement be so fundamental a breach of the contract of employment at present in existence between the parties as to entitle the workers to say "you cannot order us to do this, we are entitled to cancel the contract of employment and to treat your direction as a dismissal"? 


\section{Rebecca Macfie}

In Armourguard, the answer to the question was "no". It was neither an express nor implied term of the employees' contracts that consultation take place. In IHC, however, the employer's action in breaching its employees' contracts, with the effect of immediately reducing their earnings, was held to be such a fundamental breach that it constituted a lockout under s62(1)(c). The implication of the fundamental term test, and its application in IHC, seems to be that the more an employer's action goes to the very heart of the employee/employer relationship - that is, to their wages and conditions and other matters embodied in the employment contract - the more likely the action will be held to be a lockout and therefore, provided the action is lawful, immune from compliance orders or injunctions.

The IHC decision also underlines the absence of any requirement under the ECA (as under the LRA) to bargain in good faith. Drawing on NZ Public Service Association' $v$ Armourguard Rescue Services Ltd [1989] 2 NZILR 405, Castle J held the only relevant issue for the Court was whether negotiations were being held, not their quality or the bargaining strength of the parties. (See also Hyndman and Unkovich v Air New Zealand Ltd 16/10/91 AEC 19/91 A250 and A251.91 at page 3).

Taken together, Prendergast and $I H C$ reveal the manner in which employers can lawfully thrust change on employees when negotiations have failed to produce the desired settlement. Thus the decisions create an irreconcilable conflict with the ECA's fundamental premise of sanctity of contract, and with earlier decisions upholding that principle (for instance, Resident Doctors' Assn v Otago Area Health Board [1991] 2ERNZ (CLC 41), and Grant $v$ Superstrike Bowling Centres Ltd ALC 81/91). The ability to use s62(1)(c) to target unwanted provisions in contracts has directly undermined s19(4) of the ECA, which provides that when a CEC expires employees are deemed to be on IECs based on the terms of the expired CEC. In the light of IHC and Prendergast, s19(4) need not impede a determined employer from imposing its will on employees. It is ironic to note that some cases concerning breaches of s19(4) (for example, United Food and Chemical Workers' Union $v$ Talleys Fisheries Ltd unreported, 9 August 1991 WLC 73/91) may have produced different results had the employer sought the protection of s62(1)(c).

Further, the ability of employers to follow the example of $I H C$ and, in effect, impose new terms on employees, undermines the very object of Part IV of the ECA, which establishes that employment contracts create enforceable rights and obligations and that the primary remedy for any breach of contract is a compliance order. Provided an employer can establish it has acted lawfully under s62(1)(c), workers can expect no relief from the Court.

Significantly, Castle $\mathrm{J}$ in $I H C$ rejected the view of his colleague Colgan $\mathrm{J}$ in Air New Zealand (supra). Colgan $J$ found that the definition of lockout at $\mathrm{s} 232(1)$ (c) of the LRA contemplated compliance with a demand that was independent of the events which constituted the breach of the contract of employment. In Air New Zealand it was held the demand and the breach were one and the same thing - that pilots be clean-shaven.

This interpretation has been aptly described as "involving a gloss to the plain words of the s62 definition of lockout" (Toogood, 1992). Section 62(1)(c) contemplates the act of the employer in "... breaking some or all of the employer's employment contracts ... with a view to compelling any employees ... to accept terms of employment or comply with any demands made by the employer". There seems no suggestion from a plain reading of s62 that the action of the employers in IHC and Prendergast in breaking the employment contracts in a manner that corresponded precisely with the demands they were making of the employees did not fall within the ambit of the section. Obviously, however, had Colgan J's analysis in 
Air New Zealand been correct, the climate for employers wanting to unilaterally impose changes on workers would have been considerably more hostile than it now is as a result of IHC and Prendergast.

In IHC Castle J pointed to the need only to illustrate that negotiations for a CEC were being conducted before a lockout could be lawful under s64(1)(b), and held that the bargaining strength of the parties and quality of the negotiations were irrelevant to the Court. In fact, in the subsequent Designpower case (supra), even this meagre requirement appears to have been abandoned by the Court. In this case Designpower employees, aware the company wanted to reduce their redundancy entitlement prior to laying off part of its workforce, refused to negotiate for a CEC and told the company they wanted IECs. The company threatened to lock them out with a view to compelling them to negotiate a CEC. The employees' agent, the PSA, alleged the lockout was unlawful because it did not relate, to the negotiation of a CEC, and because it offended against s63(1)(d), which prohibits strikes and lockouts relating to the ECA's freedom of association provisions. Colgan J held that the lockout was lawful even though negotiations for a CEC were not underway. The action related to the negotiation of a CEC, in the sense that the company wanted to compel its employees to negotiate with it for such a contract. It was held that Parliament had not intended $s 64(1)(b)$ to be restricted to circumstances where negotiations had actually commenced.

The PSA's allegation that the lockout threat offended against 55 of the ECA (which establishes the right of employees to choose whether to associate for the purposes of advancing their collective employment interests, and that no undue influence can be brought to bear on any person by reason of that person's association or lack of association with other employees) also failed. Colgan $\mathrm{J}$ held that $\mathrm{s} 5$, as an objects section, did not confer substantive rights.

It has been suggested that this decision will put employees in a strong position when dealing with employers who refuse to negotiate for a CEC. That may be so. But the impact of the decision is nevertheless to tip the balance of bargaining power clearly in favour of employers. Designpower sanctions the use of lockouts to coerce employees to associate with one another to negotiate a CEC. Employees, however, are specifically denied the corresponding power by s63(e) of the ECA, which makes it unlawful for employees to strike with a view to compelling employers to associate together for the purpose of negotiating a CEC.

The idea of the lockout as the "mirror image and quid pro quo" of the strike is further undermined by the Court's ruling in Hawtin v Skellerup Industrial Ltd CEC 28/92 C 8/92 $16 / 6 / 92$. In that case the company issued lockout notices to two workers to compel them to agree to a CEC. After one of the workers agreed to sign the contract the company proceeded to lock out the sole remaining dissident. Palmer $\mathrm{J}$ held that the legislation allowed the lockout of a single worker, even though the definition of lockout at s62 referred to employees in the plural. It was held that there was "no conceptual problem, either in logic or in law" presented by a lockout of one worker who refused to sign a CEC which, by definition, must bind two or more employee parties. It did not logically follow that, because a common understanding, agreement or concerted action by employees was a prerequisite to a strike, a lockout in a corresponding opposite way must extend to two employees. While strikes and lockouts were opposites, they had distinctly different constituents which were not simply the reverse of the differing elements of each.

At first glance the ECA may have appeared to confer some protection against coercive lockout action under s57, which provides remedies against contracts procured by harsh and 
oppressive behaviour, undue influence or duress. However, Adams and Ors $v$ Alliance Textiles (NZ) Ltd [1991] 2 ERNZ (CEC 22) effectively dispels this possibility. In this case it was argued employees were coerced into agreeing to new contracts by the employer's imposition of a lockout, and that this amounted to economic duress. Goddard CJ held that the lockout in question was lawful and did not amount to duress. The Chief Judge's analysis of the law on whether, in the industrial relations context, a lawful act can constitute economic duress leaves little scope for employees to seek the shelter of $s 57$ in the event of a lawful lockout. It was noted that the ECA did not grant immunity for lawful strikes and lockouts from proceedings under $s 57$, as it did from proceedings in tort (s73) and from applications for injunction (s74), and that an allegation of duress arising from a lockout which may be lawful could not be dismissed out of hand by the Court and must be treated seriously. But the Court would necessarily approach such a suggestion with caution, the main reason being that Parliament had recognised the legitimacy of strikes and lockouts in certain circumstances. To recognise lockouts as amounting to economic duress would carry the same consequence for strikes. Therefore, "there would need to be a most exceptional set of circumstances to justify [such a finding]". In holding that the facts of the Alliance case did not warrant such a finding, Goddard CJ gave a clear indication of the difficulty employees would face in seeking the protection of $\mathrm{s} 57$ in lawful lockout situations:

It may have been otherwise (I put it no more strongly than that) if there had been a prolonged lockout finally bringing employees to their knees by virtually starving them into submission to the employer's demands ...

\section{The power of the lockout: is the ECA responsible?}

It has been argued that the IHC style of lockout could have occurred under the LRA and is not the result of the ECA (Birch, 1992). The crux of this argument is that the definition of lockout is the same under the ECA as it was under the LRA. Banks (1992), however, argues that while IHC-style lockouts could in theory have occurred under the LRA, in practice they were most unlikely given the LRA's provision for awards and agreements to continue in force for up to three years beyond their expiry dates (s171) and the provision for awards and agreements to prevail over contracts of service in cases of conflict (s174).

Banks' proposition calls for further development. The fact that an award or agreement could continue in force for up to three years beyond its expiry date did not preclude lawful strikes or lockouts over disputes of interest during that time. Hughes (1989) notes that the right to strike or lockout did not cease when the document expired. It was not unknown under the LRA for a dispute of interest to remain live for a protracted period after the document's expiry date, and therefore for the opportunity to take lawful strike or lockout action to remain open.

The reason IHC-style tactics were unknown under the LRA lies in the nature of bargaining under that regime, and in particular the nature of award bargaining. Technically an employer under the LRA could, in the context of a dispute of interest where the document in question had less than 60 days to run, have imposed a partial lockout under s232(1)(c). However the reality of award bargaining, whereby nominated employer and union representatives were authorised to reach settlements which in many cases bound thousands of employers across entire industries, was that industrial action by an individual employer 
would have been ineffective.

Take a practical example. ABC Welding is covered by the metal trades award. That award is due to expire in 60 days and the Engineers' Union has created a dispute of interest to initiate negotiations for its renewal. For its part, $\mathrm{ABC}$ wants to lower its base pay rate by $1 \%$ and imposes such a cut under the auspices of s232(1)(c). ABC's employer representatives then settle the award with the union on the basis of a $2 \%$ increase in the base pay rate. By virtue of the award's subsequent parties provision, $\mathrm{ABC}$ is bound by the new document, and because the dispute is settled the lockout is no longer lawful. The end result is that $A B C$ has achieved nothing more than a temporary lowering of its wage bill, has brought no influence to bear on the award negotiations, and has probably seriously marred its relationship with its employees.

The only circumstance in which ABC's action may have been effective would have been if it was part of a concerted and widespread campaign by other employers bound by the same award. And even then, the ability of all workers covered by the award to mount retaliatory strike action would most likely have been enough to deter employers from taking such unilateral action. However it is conceivable that the partial lockout could have been used to effect under the LRA in the context of cited party agreements, particularly enterprise deals where the employer taking the lockout action would also have been an original party to any final settlement.

The Hawtin case, too, would have been practically, if not theoretically, impossible under the LRA. Under that regime unions, rather than individual workers, were parties to awards and agreements. In principle a single employee (assuming the Labour Court adopted the same approach as Palmer $\mathrm{J}$ in Hawtin) could have been locked out in the context of a dispute of interest, but the collective nature of bargaining, whereby the focus was on the union rather than the individual worker, meant such action would have been fruitless (if not completely counter-productive) for the employer. Also, once the document in dispute was settled it would have been impossible for an individual worker to hold out against it, so the prospect of a lawful lockout of a single employee could not have arisen.

There is another aspect to the bargaining environment created by the ECA that supports the proposition that lockouts are a more readily available and powerful tool now than they were under the LRA. The LRA, prior to the introduction of the 1990 amendment, imposed no requirement on the parties to negotiate in good faith. This was noted in Armourguard (supra) in a passage adopted by Castle $\mathrm{J}$ in the $I H C$ ruling to illustrate that this permissive approach still applies under the ECA:

... there is no compulsory arbitration, there is no sanction against a party which refuses to negotiate, and it is because of these considerations that workers have been given a limited right to strike as the only means available to compel employers to negotiate.

But in Hyndman (supra), Colgan J suggested the ECA had gone further than the LRA in this respect, by removing any "legitimate expectation" that the employer would continue to negotiate with its employees:

Although under the previous industrial regime employees may have expected a degree of continued negotiations, under the new negotiation can include the option of declining or refusing to negotiate or at least of coming by a process of negotiation to a final offer position in default of acceptance of which other lawful options may be resorted to.

The basis of such a "legitimate expectation" under the LRA was not discussed in the 
ruling, but it is arguable that such an expectation stemmed from sections (b) and (c) of the Act's long title, namely "to provide procedures for the orderly conduct of relations between workers and employers" and "to provide a framework to enable agreements to be reached between workers and employers". The whole thrust of the formal structure of award bargaining through the compulsory conciliation process and, in the latter stages of the LRA, the availability of limited compulsory final offer arbitration, was to facilitate settlements between unions and employers. Although voluntary agreements were settled outside the compulsory conciliation process, the Mediation Service and Arbitration Commission were nevertheless available to the parties to assist in achieving settlements.

In addition, the LRA contained a range of special powers in relation to strikes and lockouts. Section 244 granted the chief mediator power to inquire into disputes in essential industries where the public interest was affected or threatened by an existing or threatened strike or lockout, and to attempt to settle the dispute. Section 245 gave the Ministef of Labour power in such circumstances to ask a mediator to inquire into the dispute, following which, under s246, the Labour Court could be called on to settle the dispute or to set out how it should be settled. Under s247 the Minister could call a conference of the parties, and if they failed to attend, the conference chairman could make a final and binding settlement. Section 248 allowed the Minister to appoint a committee of inquiry into a dispute, and finally, s249 allowed a mediator to call a conference to try and settle a dispute.

With the exception of $s 249$, these provisions were rarely used, but in combination with the bargaining process, were indicative of an industrial relations culture in which there prevailed an expectation of negotiation. The ECA, by contrast, has established a minimalist bargaining regime from which the Mediation Service and Arbitration Commission have been abolished, and which contains none of the special provisions in relation to strikes and lockouts listed above. As has been noted, the ECA is entirely neutral as to whether settlements are achieved and imposes neither an expectation nor an obligation on the parties to employment contracts to negotiate.

There is one final and highly significant feature of the ECA which has contributed to the emergence of the lockout as a more powerful tool than it was under the LRA. Under the LRA an employer imposing a lockout, particularly under s232(1)(a), (b) and (d), could conceivably have employed alternative labour to replace the locked out employees. But provided an award or agreement was in force the employer would have had to engage those workers under the terms of the same document that applied to the locked out workers. In other words, there would have been no immediate financial advantage to the employer in doing so. Also, as was likely, if the relevant award or agreement contained a compulsory union membership clause the replacement workers would have had to become members of the very union which was opposing the employer's demands. That union would have had exclusive bargaining rights over the replacement workers, as well as over any permanent workers who chose to return to work on the employer's terms. The system permitted little practical possibility of alternative representation to undermine the standing of the union with coverage of the site.

The ECA has changed all that. Because employment contracts bind only the direct parties, employers can replace locked out (or striking) workers with cheaper labour, which, at the very least, reduces the financial cost of mounting a campaign of industrial action. Unionism is now voluntary, so replacement workers need not feel the disciplinary wrath of their union officials for "scabbing" on their fellow workers. Indeed, under the ECA it is open to them to set up a rival "employee organisation" to challenge the status of the union with traditional coverage of the site. 
A graphic example of these points was the Christchurch Carpet Yarns dispute in early 1992. In that dispute, about half the workforce refused to agree to the employer's demands for a new CEC, and were locked out. The remainder of the workforce signed the new CEC and returned to work, and replacement employees were recruited on the terms of the new $\mathrm{CEC}$ to fill in for the locked out workers. A new employee organisation was formed during the lockout to represent those who were working under the new CEC. Thus the company was able to minimise the cost of the dispute, which ended when the locked out workers agreed to return to work on the employer's terms.

\section{Conclusion}

The sum total of these changes to the bargaining process is that employers, particularly in an economic climate of high unemployment which gives them the upper hand, can effectively exchange sincere negotiation with force by imposing changes on workers through lockouts, provided they can demonstrate they are acting lawfully within the meaning of s64.

The Minister of Labour and his officials (Department of Labour, 1992) have argued, in response to alarm at the implications of the $I H C$ decision, that the law is neutral between strikes and lockouts. This comment defies the reality of the employment relationship. It is true that workers may breach sections of their contracts by way of strike action, just as the IHC breached parts of its contracts. But in practice the impact of the two forms of action can never be "neutral". There is simply no circumstance in which employees could make a demand of an employer and then impose the desired change by way of strike action without themselves incurring financial loss. Only the employer is in the position of being able to make a demand and then, by exercising its control of the business, impose the change through industrial action. An employer can demand and then impose a pay cut; employees can demand a pay rise but cannot impose it. Even if, for instance, employees were to demand a shorter working week and then impose it by not turning up on the hours they wanted to be relieved of, they would suffer immediate financial loss because the employer would not be obliged to pay them for those hours.

The body of case law that has developed since the ECA was introduced has effectively closed off the avenues for workers to resist employer demands, and undermined their purported rights under the ECA. In particular, it has made a mockery of the Minister of Labour's assurances that employees' contracts could not be unilaterally changed by employers. As $I H C$ and Prendergast have shown, employers can do just that, provided they select the circumstances in which they act to ensure the legality of the move.

The Minister of Labour has defended the ECA and the recent case law on lockouts with the comment that "employers regard lockouts as an action to be taken only in the last resort ... lockouts, including partial lockouts, have the potential to seriously damage employee/employer relationships" (Birch, 1992), and that strikes or lockouts are generally taken by one party or the other as a short term measure. These comments are based on the expectation of reasonable industrial relations behaviour, which allows the Minister to evade the reality that the new regime has opened up enormous potential for employers to lawfully force their will on their employees. What needs to be addressed is not how the parties in industrial relations ought to behave, but the scope for unreasonable and unfair behaviour that the legislation tolerates.

In this respect, it is suggested the following changes would go some way to restoring 
the balance to the employee/employer relationship without threatening the philosophical integrity of the ECA:

- a requirement or expectation that employers and employees negotiate in good faith, thereby reducing the potential that now exists for employers to simply state their demands and then peremptorily enforce them through lockout action.

- a prohibition on employers making a demand of employees, and then enforcing that demand through lockout action under $\mathrm{s} 62(1)(c)$. This suggestion takes its lead from the ruling of Castle J in Air New Zealand (supra) which was subsequently rejected in the $I H C$ case. This would significantly curtail the potential for employers to adopt the tactics in IHC and Prendergast and effectively unilaterally vary their employees' terms and conditions, and would therefore restore credibility to the Minister of Labour's assurances that such unilateral variations could not occur under the ECA.

- the repeal of s63(e), which prevents employees from striking over the issue of whether a CEC will bind more than one employer. The Designpower case sanctions the use of lockouts to force employees to associate with one another for the purpose of negotiating a CEC, yet employees are specifically deprived of the corresponding right to strike to force employers to associate together for a CEC. Repeal of s63(e) would redress this imbalance.

\section{References}

Banks, B. (1992), Commentary on the IHC case, Industrial Law Bulletin, 1992.

Birch, Hon. B., The Christchurch Press, 21 June 1992.

Brosnan, P., Smith, D., and Walsh, P. (1990), The Dynamics of New Zealand Industrial Relations, John Wiley and Sons.

Churchman, P. (1991), Tracing the Arc of the Pendulum: The regulation of collective bargaining in New Zealand, New Zealand Law Journal, September and October.

Dept of Labour, briefing note to Minister of Labour, 16 January 1992.

Geare, A. (1988), The System of Industrial Relations in New Zealand, second edition, Wellington, Butterworths.

Harbridge, R., Flexibility in Collective Bargaining in New Zealand, New Zealand Journal of Industrial Relations, 15(3):241-250.

Harbridge, R. (1991), Collective Bargaining and the Employment Contracts Bill, Paper presented to Employment Contracts seminar, Wellington, 1991. 
Harbridge, R. and Moulder, J. (1992), Collective Bargaining and the Employment Contracts Act: One Year On, Paper presented to industrial relations seminar, Wellington, May 1992.

Hughes, J. (1989), Labour Law in New Zealand, Australia, The Law Book Company Ltd.

McAndrew, I., and Hursthouse, P., Southern Employers on Enterprise Bargaining, New Zealand Journal of Industrial Relations, 15(2):117-128.

Toogood, C. (1992), Address to AIC industrial relations conference, 17 \& 18 February. 